\title{
Faktor-faktor pada kejadian GAKY ibu hamil di Tabunganen Barito Kuala, Kalimantan Selatan
}

Alfitri', Untung S. Widodo ${ }^{2}$, Toto Sudargo ${ }^{3}$

\begin{abstract}
Background: lodine Deficiency Disorder (IDD) is a health problem that affects quality of human resources. IDD happens not only due to iodine deficiency but also other disorders such as goitrogenic substance (thiocyanate), pollutants of heavy metals $(\mathrm{Pb})$ and micronutrient deficiency $(\mathrm{Fe})$ that inhibit thyroid hormone biosynthesis which cause the sweling of goitre glands.

Objective: To identify the association between consumption of iodine, thiocyanate, Fe consumption, status of anemia and $\mathrm{Pb}$ and status of IDD in pregnant mothers at Subdistrict of Tabunganen, District of Barito Kuala, Province of Kalimantan Selatan.

Method: The study was observational using case control design and quantitative method. Data were obtained through the palpation of goitre glands, measurement of thyroid stimulating hormone (TSH) level using ELISA method, iodine and thiocyanate consumption using food recall $2 \times 24$ hours and food frequency questionnaire (FFQ), Fe consumption using FFQ, Hb level using photometric method and Pb level using AAS method. Data were analysed by using chi-square and logistic regression.

Result: There was significant association $(p<0.05)$ between consumption of iodine (fish) based on FFQ and IDD status (goitre) with $O R=3.44$ and IDD status $(T S H)$ with $O R=8.00$. There was no association between consumption of thiocyanate and Fe measured with food recall, FFQ and IDD status (goitre and TSH). There was significant association $(p<0.05)$ between $P b$ status and IDD status $(T S H)$ with $O R=9.35$.

Conclusion: There was association between iodine consumption based on FFQ (fish) and IDD status (goitre) after the control of iodine consumption status (food recall). There was association between iodine consumption status (FFQ) in fish together with anemia status and the prevalence of IDD disorder (TSH) after the control of Pb status.
\end{abstract}

KEYWORDS: iodine deficiency disorder, pregnant mothers, iodine, thiocyanate, Fe, anemia, Pb

\begin{abstract}
ABSTRAK
Latar Belakang: Gangguan akibat kekurangan yodium (GAKY) merupakan masalah kesehatan yang dapat mempengaruhi kualitas sumber daya manusia. GAKY tidak hanya disebabkan oleh kekurangan yodium, tetapi juga dipengaruhi oleh zat goitrogen(tiosianat), logam berat $\mathrm{Pb}$, dan kekurangan Fe yang menghambat biosintesis hormon dan berakibat pada pembesaran kelenjar gondok.

Tujuan: Mengetahui hubungan antara tingkat konsumsi yodium, goitrogen (golongan tiosianat), Fe, serta status anemia dan status $P b$ dalam darah dengan status GAKY pada ibu hamil di Kecamatan Tabunganen Kabupaten Barito Kuala Provinsi Kalimantan Selatan.

Metode: Penelitian ini merupakan penelitian observasional dengan rancangan case control. Data pembesaran kelenjar tiroid diperiksa denganpalpasi di daerah kelenjar tiroid, kadar TSH dengan metode ELISA, tingkat konsumsi yodium dan tingkat konsumsi tiosianat dengan metode food recall $2 \times 24$ jam dan food frequency questionnaire (FFQ), tingkat konsumsi Fe dengan FFQ, kadar $\mathrm{Hb}$ dalam darah dengan metode fotometrik, kadar $\mathrm{Pb}$ darah dengan metode AAS.Data dianalisis menggunakan chi-square dan logistic regression.

Hasil: Ada hubungan signifikan $(p<0,05)$ antara tingkat konsumsi yodium (ikan laut) berdasarkan $F F Q$ dan status terhadap status GAKY (gondok) dengan OR=3,44 dan status GAKY (TSH) dengan OR=8,00. Tidak ada hubungan antara tingkat konsumsi tiosianat dan Fe yang diukur dengan food recall, FFQ, dan status GAKY (gondok dan TSH). Antara status $\mathrm{Pb}$ dan status GAKY (TSH) juga tidak ditemukan adanya hubungan dengan $O R=9,35$.

Kesimpulan: Ada hubungan antara konsumsi yodium berdasarkan FFQ (ikan laut) dan status GAKY (gondok) dan antara konsumsi yodium (FFQ) dengan status anemia dan prevalensi GAKY (TSH).
\end{abstract}

KATA KUNCl: gangguan akibat kekurangan yodium, wanita hamil, yodium, tiosianat, Fe, anemia, $\mathrm{Pb}$

\footnotetext{
${ }^{1}$ Dinkes Batola Kalsel/Dinkes Kab. Barito KualaJl. Jend. Sudirman No. 62, Marabahan, Batola, Kalsel 70513, e-mail:alf_19_34@yahoo.co.id Balai GAKY, Kapling Jayan, Borobudur Magelang, Jawa Tengah 565536

${ }^{3}$ Prodi Gizi Kesehatan Fakultas Kedokteran Universitas Gadjah Mada, Jl. Farmako, Sekip Utara, Yogyakarta 55281, e-mail.totosud@indosat.net.id
} 


\section{PENDAHULUAN}

Gangguan akibat kekurangan yodium (GAKY) merupakan salah satu masalah gizi pada masyarakat di Indonesia, mengingat dampaknya yang secara langsung atau tidak langsung mempengaruhi kelangsungan hidup dan kualitas sumber daya manusia yang mencakup 3 aspek, yaitu aspek perkembangan kecerdasan, perkembangan sosial, dan perkembangan ekonomi (1). Selain pembesaran kelenjar gondok, kekurangan yodium yang terjadi sejak janin menyebabkan bayi baru lahir kretin dengan retardasi mental, pendek, muka, tangan sembab, dan kelemahan otot. Pada anak-anak ditandai adanya retardasi pertumbuhan dan mental (2).

Defisiensi yodium selama masa kehamilan berdampak buruk pada perkembangan otak fetus yang mulai terjadi pada kehamilan trimester kedua dan terus berlanjut sampai akhir kehamilan. Jika Ibu mendapat suplemen zat yodium, dampak buruk ini dapat berkurang. Defisiensi yodium berat dalam kurun waktu lama (kronis) menyebabkan kemungkinan untuk pulih (functional recovery) makin kecil. Hal ini berarti kelainan fisik dan mental yang terjadi pada janin akan menjadi permanen sampai dewasa. Adapun dampak buruk pada janin yang lain akibat defisiensi yofium ini dapat berupa: keguguran, lahir mati, lahir cacat, dan terganggunya perkembangan otak $(3,4)$.

Berdasarkan hasil pemetaan GAKY nasional tahun 2003, diketahui TGR (total goiter rate) di semua kabupaten di Provinsi Kalimantan Selatan tergolong nonendemik (TGR $<5 \%$ ), kecuali di Kabupaten Barito Kuala yang tergolong endemik ringan dengan TGR sebesar 9,2\% (5). Dari data Dinas Kesehatan Kabupaten Barito Kuala tahun 2003 dilaporkan Kecamatan Tabunganen yang berada di daerah muara sungai Barito dan pantai merupakan daerah dengan TGR terbesar $(29,17 \%)$.

Kekurangan yodium merupakan faktor paling penting pada kejadian GAKY, namun pada beberapa observasi diketahui bahwa faktor lingkungan mempunyai pengaruh yang bermakna terhadap menetap dan berkembangnya kasus GAKY baru. Faktor lingkungan itu antara lain adanya senyawa goitrogen (zat yang dapat menghambat pengambilan yodium oleh kelenjar gondok, sehingga kandungan yodium dalam kelenjar menjadi rendah, berakibat pada kekurangan yodium), seperti kelompok tiosianat pada ubi kayu, jagung, rebung, ubi jalar, dan buncis besar (6). Selain senyawa goiterogen, juga didapati adanya berbagai zat yang berpengaruh terhadap metabolisme yodium, yang juga berpengaruh terhadap kejadian, kegawatan, dan prognosis GAKY (7). Zat gizi yang menyebabkan timbulnya GAKY antara lain: selenium $(\mathrm{Se})$, seng $(\mathrm{Zn})$, vitamin $\mathrm{A}$, tembaga $(\mathrm{Cu})$, besi $(\mathrm{Fe})$, dan adanya polusi logam berat $(\mathrm{Pb}, \mathrm{Hg}$ dan $\mathrm{Cd})(7,8)$.

Penelitian Zimmermann et al. (9) menunjukkan bahwa kekurangan Fe dapat menyebabkan terganggunya metabolisme tiroid dalam tubuh manusia. Hal ini dipertegas oleh Wegmulleret al. (10) yang menyatakan bahwa fortifikasi yodium dan Fe dapat meningkatkan penyerapan Fe dalam tubuh.

$\mathrm{Pb}$ dalam tubuh akan membentuk ikatan yang kuat dengan unsur yodium, sehingga yodium tidak dapat digunakan untuk biosintesis hormon kelanjar tiroid (8). Kelebihan $\mathrm{Pb}$ pada suatu organisme juga mempengaruhi metabolisme sel darah merah dan menghambat enzim pada biosintesis heme yang pada akhirnya menyebabkan anemia (11). Sementara itu, penelitian di salah satu pantai Kalimantan Selatan menunjukkan bahwa rata-rata kandungan $\mathrm{Pb}$ di perairan Pantai Takisung dan Batakan Kabupaten Tanah Laut telah melebihi ambang batas (12).

Tujuan penelitian ini untuk mengetahui hubungan antara tingkat konsumsi yodium, goitrogen (golongan tiosianat), $\mathrm{Fe}$, status anemia, dan status $\mathrm{Pb}$ dalam darah dengan status GAKY pada ibu hamil di Kecamatan Tabunganen Kabupaten Barito Kuala Provinsi Kalimantan Selatan.

\section{BAHAN DAN METODE}

Jenis penelitian ini adalah observasional dengan rancangan case control yang dilaksanakan pada bulan JuliSeptember 2008. Populasi penelitian adalah seluruh Ibu hamil di Kecamatan Tabunganen Kabupaten Barito Kuala, sedangkan sampel penelitian adalah 38 ibu yang hamil dengan gondok dan 40 ibu hamil non-gondok. Kriteria inklusi meliputi ibu hamil yang tinggal di daerah penelitian minimal 6 bulan terakhir dan bersedia menjadi subjek penelitian, sedangkan Kriteria eksklusi meliputi ibu hamil yang sakit infeksi, mengalami komplikasi kehamilan, dan pindah ke luar kecamatan penelitian. Pemilihan ibu hamil untuk menjadi responden pada penelitian ini berdasarkan kasus adanya gondok atau pembesaran kelenjar tiroid (grade 1 dan 2). Kontrol adalah ibu hamil yang tidak gondok atau tidak mengalami pembesaran kelenjar. Jumlah ibu hamil yang bersedia menjadi responden penelitian sebanyak 78 orang dengan jumlah kasus sebanyak 38 responden (28 ibu hamil grade 1 dan 10 ibu hamil grade 2) dan kontrol sebanyak 40 ibu hamil grade 0 . Selain itu, variabel kadar TSH pada responden juga dijadikan variabel terikat untuk penelitian ini.

Pembesaran kelenjar tiroid diperiksa dengan cara palpasi (perabaan) di daerah kelenjar tiroid, kadar TSH (thyroid stimulating hormone) dengan metode ELISA (enzyme-linked immunosorbent assays), tingkat konsumsi yodium dan tiosianat diukur dengan metode food recall $2 \times 24$ jam dan food frequency (FFQ), tingkat konsumsi Fe diukur dengan metode food recall $2 \times 24$ jam, kadar $\mathrm{Hb}$ dalam darah diukur dengan metode photometric menggunakan alat AutoCounter, dan kadar $\mathrm{Pb}$ darah diukur dengan metode AAS (atomic absorption spectrometry).

Analisis data untuk mengetahui hubungan antarvariabel menggunakan uji Chi Square. Untuk 
menguji kontribusi variabel bebas yang secara bersamaan berpengaruh terhadap variabel terikat menggunakan regresi logistik.

\section{HASIL DAN BAHASAN}

\section{Prevalensi GAKY}

Ibu hamil yang tercatat di Puskesmas Tabunganen sebanyak 227, namun yang bersedia ikut dalam pemeriksaan palpasi gondok sebanyak 152. Berdasarkan hasil pemeriksaan palpasi gondok ibu hamil, diketahui sebanyak $33(21,71 \%)$ ibu hamil termasuk dalam pembesaran grade 1 dan sebanyak $10(6,58 \%)$ ibu hamil tergolong pembesaran grade 2 . Total pembesaran (grade 1 dan grade 2) di Kecamatan Tabunganen sebanyak 43 $(28,29 \%)$ ibu hamil, sehingga digolongkan sebagai daerah endemik sedang.

Hasil pemeriksaan terhadap 147 ibu hamil menunjukkan bahwa konsentrasi EYU (ekskresi yodium urine) berkisar antara 8-456 $\mathrm{\mu g} / \mathrm{L}$ dengan median EYU sebesar $129 \mu \mathrm{g} / \mathrm{L}$. Dengan menggunakan batasan median EYU yang sebesar $150 \mu \mathrm{g} / \mathrm{L}$ (13), asupan yodium di Kecamatan Tabunganen tergolong kurang. Terdapat 86 $(58,50 \%)$ ibu hamil dengan status intake yodium kurang (EYU < $150 \mu \mathrm{g} / \mathrm{L}), 44(29,93 \%)$ ibu hamil dengan status cukup (EYU 150-249 $\mu \mathrm{g} / \mathrm{L}$ ), dan 17(11,56\%) ibu hamil dengan status intake yodium lebih dari cukup (EYU 250$499 \mu \mathrm{g} / \mathrm{L})$.

Distribusi EYU pada responden menunjukkan median pada kasus $(115 \mu \mathrm{g} / \mathrm{L})$ lebih kecil daripada median kontrol (124 $\mu \mathrm{g} / \mathrm{L})$ dan memiliki kesamaan di bawah median normal dengan sebagian besar responden memiliki EYU kurang dari $150 \mu \mathrm{g} / \mathrm{L}$ baik pada kasus $(67,60 \%)$ maupun pada kontrol $(57,50 \%)$. Mengingat besarnya dampak GAKY pada ibu hamil (terutama terhadap kesehatan ibu dan perkembangan anak), selain pemeriksaan palpasi dan EYU, perlu juga dipertimbangkan pemeriksaan TSH (4). Kadar TSH >5 mU/L merupakan tanda kerawanan perkembangan otak janin, berisiko aborsi, dan anak lahir mati (14). Batas TSH normal di Indonesia sekitar 0,5-5 mU/L (2). Berdasarkan pemeriksaan TSH serum responden di Kecamatan Tabunganen, terdapat $9(11,54 \%)$ responden dengan kadar $\mathrm{TSH}$ serum $>5 \mathrm{mU} / \mathrm{L}$. Hal ini menunjukkan adanya penurunan T4 (hipotiroid) pada $11,5 \%$ responden. Penelitian ini sesuai dengan laporan Vaidya et al. (2007) yang menunjukkan peningkatan TSH pada kelompok ibu hamil berisiko GAKY dengan RR (risk ratio) 6,5 kali (Cl95\%:3,3-12,6; $p<0,0001)(15)$.

Hasil pemeriksaan TSH juga menunjukkan 6 $(7,69 \%)$ responden dengan kadar $\mathrm{TSH}$ serum $<0,5$ $\mathrm{mU} / \mathrm{L}$. Penurunan kadar TSH serum menggambarkan adanya peningkatan T4 (hipertiroid). Penderita hipertiroid menunjukkan konsentrasi TSH yang lebih kecil daripada normal dan seringkali nol (16).
Batasan normal TSH di setiap negara berbeda-beda dan pada umumnya lebih rendah dibanding Indonesia. Zimbabwe memiliki batasan normal TSH 0,2-5,0 mU/L (17), di Rumah Sakit James Cook University 0,27-4,2 $\mathrm{mU} / \mathrm{L}$ (15), penelitian pada National Health and Nutrition Examination Survey (NHANES) di Amerika menggunakan batasan normal TSH 0,1-4,5 mU/L (18), dan di Turki dengan batasan normal TSH adalah 0,27 - 4,2 mU/L (19). Dalam rangka kebijakan program penanggulangan GAKY, batasan normal TSH di Indonesia perlu dikaji lebih jauh.

\section{Penanggulangan GAKY}

Upaya penanggulangan GAKY di Kecamatan Tabunganen dapat dilihat dari penggunaan garam beryodium, distribusi kapsul yodium, dan penyuluhan tentang GAKY pada responden selama masa kehamilan (Tabel 1).

\section{Tabel 1.Distribusi responden berdasarkan pencapaian upaya penanggulangan GAKY (gangguan akibat kekurangan yodium)}

\begin{tabular}{lcccccc}
\hline Upaya & \multicolumn{2}{c}{ Kasus } & \multicolumn{2}{c}{ Kontrol } & \multicolumn{2}{c}{ Total } \\
\cline { 2 - 7 } penanggulangan & $\mathbf{n}$ & $\%$ & $\mathbf{n}$ & $\%$ & $\mathbf{n}$ & $\%$ \\
\hline $\begin{array}{l}\text { Garam bermerk } \\
\quad \text { Tidak ada }\end{array}$ & 0 & 0 & 0 & 0 & 0 & 0 \\
$\quad$ Ada & 38 & 100 & 40 & 100 & 78 & 100 \\
$\quad$ Jumlah & 38 & 100 & 40 & 100 & 78 & 100 \\
Tes garam & & & & & & \\
$\quad$ Tidak & 2 & 5,3 & 3 & 7,5 & 5 & 6,4 \\
$\quad$ beryodium & & & & & & \\
$\quad$ Beryodium & 36 & 94,7 & 37 & 92,5 & 73 & 93,6 \\
$\quad$ Jumlah & 38 & 100 & 40 & 100 & 78 & 100 \\
Kapsul yodium & & & & & & \\
$\quad$ Tidak dapat & 18 & 47,4 & 16 & 40 & 34 & 35,9 \\
$\quad$ Dapat & 20 & 52,6 & 24 & 60 & 44 & 64,1 \\
$\quad$ Jumlah & 38 & 100 & 40 & 100 & 78 & 100 \\
$\begin{array}{l}\text { Penyuluhan GAKY } \\
\quad \text { Tidak pernah }\end{array}$ & 33 & 86,8 & 39 & 97,5 & 72 & 92,3 \\
$\quad$ Pernah & 5 & 13,2 & 1 & 2,5 & 6 & 7,7 \\
$\quad$ Jumlah & 38 & 100 & 40 & 100 & 78 & 100 \\
\hline
\end{tabular}

\section{Hubungan tingkat konsumsi yodium dengan status GAKY}

Gambaran tingkat konsumsi yodium dalam penelitian ini diperoleh melalui wawancara food recall (2X24 jam) dengan perhitungan kandungan yodium berdasarkan kadar yodium dalam bahan makanan (20) dan wawancara food frequency dengan perhitungan frekuensi konsumsi yodium berdasarkan skor (6).

Tingkat konsumsi yodium berdasar metode food recall. Berdasarkan hasil food recall, diketahui rata-rata konsumsi yodium sebesar 210,28 $\mu \mathrm{g} /$ hari $(S D \pm 39,43)$. Dengan menggunakan batas angka kecukupan yodium ibu hamil sebesar $200 \mu \mathrm{g} /$ hari (21), rata-rata konsumsi yodium responden tergolong cukup. Berdasarkan batas 
angka tersebut pula, konsumsi yodium $47(60,30 \%)$ responden tergolong cukup dan 31 (39,70\%) reponden tergolong kurang.

Hasil uji statistik Chi-Square menunjukkan tidak ada hubungan yang bermakna antara tingkat konsumsi yodium berdasarkan food recall dengan status GAKY (gondok) ( $p>0,05)$ (Tabel 2), demikian pula antara tingkat konsumsi yodium berdasarkan food recall dengan status GAKY (TSH) ( $p>0,05)$ (Tabel 3). Hal ini dapat disebabkan oleh konsumsi yodium pada individu yang bervariasi dari hari ke hari dan kondisi lingkungan seperti adanya senyawa goitrogen yang dapat berimbas pada menetap dan berkembangnya kasus baru (6). Selain itu, adanya berbagai zat yang berpengaruh terhadap metabolisme yodium juga dapat berpengaruh terhadap kejadian, kegawatan, dan prognosis GAKY (7).

Tingkat konsumsi yodium berdasar metode FFQ. Hasil wawancara melalui FFQ menunjukkan skor konsumsi bahan makanan sumber yodium responden dari ikan laut rata-rata sebesar 33,53 (SD $\pm 10,07)$. Hasil tersebut menggambarkan kebiasaan makan responden untuk menghidangkan menu makanan sumber yodium dari ikan laut. Berdasarkan skor rata-rata tersebut juga diketahui 50 $(64,10 \%)$ responden memiliki skor konsumsi ikan laut di atas rata-rata dan 28 (35,90\%)responden memiliki skor konsumsi ikan laut di bawah rata-rata.

Hasil uji statistik Chi Square menunjukkan hubungan bermakna antara tingkat konsumsi yodium berdasarkan FFQ dengan status GAKY (gondok) $(p<0,05)$ (Tabel 2). Responden dengan tingkat konsumsi ikan laut yang rendah berpeluang menderita GAKY 3,44 kali lebih besar
(95\% Cl:1,29-9,15) dibanding responden dengan tingkat konsumsi ikan laut yang tinggi. Hubungan bermakna juga ditunjukkan antara tingkat konsumsi yodium berdasarkan FFQ terhadap status GAKY $(\mathrm{TSH})(\mathrm{p}<0,05)$ (Tabel 3). Responden dengan tingkat konsumsi ikan laut yang rendah berpeluang menderita GAKY 8,0 kali lebih besar $(95 \%$ $\mathrm{Cl}: 1,53-41,78)$ dibandingkan dengan responden dengan tingkat konsumsi ikan laut yang tinggi.

Hasil pemeriksaan median EYU ibu hamil pada penelitian ini sebesar $129 \mu \mathrm{g} / \mathrm{L}$. Hasil tersebut kurang dari batasan median EYU normal yaitu $150 \mu \mathrm{g} / \mathrm{L}$ yang menunjukkan asupan yodium ibu hamil di Kecamatan Tabunganen tergolong kurang. Walaupun tinggal di daerah dekat laut dengan potensi hasil laut kaya sumber yodium, kecukupan yodium responden ternyata belum dapat terpenuhi. Hal ini dapat dipengaruhi oleh adanya faktor-faktor lain seperti: daya beli, penghasilan, aturan makan dalam keluarga, tabu, dan kepercayaan tertentu (22).

\section{Hubungan tingkat konsumsi tiosianat dengan status GAKY}

Zat goitrogenik yang terdapat pada kelompok tiosianat bekerja menghambat mekanisme transport aktif yodium dalam pembentukan tiroksin sehingga dapat memperparah kejadian GAKY. Data asupan yodium dalam penelitian ini diperoleh melalui wawancara food recall dengan perhitungan kandungan tiosianat (sianida) berdasarkan kadar sianida hasil analisis dari bahan makanan dan melalui wawancara FFQ dengan perhitungan frekuensi konsumsi yodium berdasarkan skor $(6,23)$.

Tabel 2. Hubungan antara tingkat konsumsi yodium, tiosianat, dan Fe dengan status GAKY (gondok)

\begin{tabular}{|c|c|c|c|c|c|c|}
\hline \multirow{3}{*}{ Tingkat konsumsi } & \multicolumn{4}{|c|}{ Pemeriksaan gondok } & \multirow{3}{*}{ OR } & \multirow{3}{*}{$\begin{array}{c}p \\
(\mathrm{Cl} 95 \%)\end{array}$} \\
\hline & \multicolumn{2}{|c|}{ GAKY } & \multicolumn{2}{|c|}{ Non-GAKY } & & \\
\hline & $\mathbf{n}$ & $\%$ & $\mathbf{n}$ & $\%$ & & \\
\hline \multicolumn{7}{|l|}{ Food recall yodium } \\
\hline Kurang & 19 & 50 & 12 & 30 & \multirow[t]{2}{*}{2,33} & \multirow[t]{2}{*}{$0,071(0,92-5,90)$} \\
\hline Cukup & 19 & 50 & 28 & 70 & & \\
\hline \multicolumn{7}{|l|}{ FFQ ikan laut } \\
\hline Rendah & 19 & 50 & 9 & 22,5 & \multirow[t]{2}{*}{3,44} & $0,011^{*}$ \\
\hline Tinggi & 19 & 50 & 31 & 77,5 & & $(1,29-9,15)$ \\
\hline \multicolumn{7}{|l|}{ Food recalltiosianat } \\
\hline Tinggi & 18 & 47,4 & 16 & 40 & \multirow[t]{2}{*}{1,35} & 0,512 \\
\hline Rendah & 20 & 52,6 & 24 & 60 & & $(0,65-0,34)$ \\
\hline \multicolumn{7}{|l|}{ FFQ tiosianat } \\
\hline Tinggi & 20 & 52,6 & 17 & 42,5 & \multirow[t]{2}{*}{1,50} & 0,370 \\
\hline Rendah & 18 & 47,4 & 23 & 57,5 & & $(0,61-3,67)$ \\
\hline \multicolumn{7}{|l|}{ Food recall Fe } \\
\hline Rendah & 16 & 42.1 & 16 & 40 & \multirow[t]{2}{*}{1,09} & 0,850 \\
\hline Tinggi & 22 & 57,9 & 24 & 60 & & $(0,44-2,69)$ \\
\hline
\end{tabular}

Keterangan:

FFQ (food frequency questionnaire)

* Bermakna pada $\mathrm{p}<0,05$ 
Berdasarkan hasil wawancara food recall, diketahui rata-rata konsumsi tiosianat sebesar 1,06 $\mu \mathrm{g} / \mathrm{hari}$ $(S D \pm 1,05)$. Jumlah ini jauh di bawah rata-rata asupan tiosianat di daerah endemik yang berkisar $15-50 \mathrm{mg}$ perhari (24). Dengan demikian dapat diketahui bahwa 34 (43,60\%) responden mengkonsumsi tiosinat di atas rata-rata dan $44(56,40 \%)$ responden lainnya mengkonsumsi tiosinat di bawah rata-rata.

Hasil uji statistik Chi Square menunjukkan tidak ada hubungan antara tingkat asupan tiosianat responden (food recall) dengan status GAKY, baik berdasarkan gondok maupun TSH $(p>0,05)$. Demikian juga hubungan antara tingkat asupan tiosianat melalui FFQ terhadap status GAKY, baik berdasarkan status gondok maupun TSH tidak menunjukkan hubungan yang bermakna $(p>0,05)$. Hal ini dapat disebabkan rata-rata konsumsi tiosianat pada responden relatif kecil $(1,06 \mu \mathrm{g} /$ hari, $S D \pm 1,05)$ sehingga tidak banyak berpengaruh terhadap status GAKY baik pada gondok maupun TSH (Tabel 2 dan Tabel 3).

\section{Hubungan tingkat konsumsi Fe dengan status GAKY}

Hasil food recall menunjukkan rata-rata asupan zat gizi Fe responden 12,63 mg per hari $(S D \pm 3,27)$ dan hasil uji statistik menunjukkan tidak ada hubungan antara tingkat konsumsi Fe dengan kejadian GAKY, baik berdasarkan status gondok maupun TSH ( $p>0,05)$ (Tabel 2 dan Tabel 3). Hasil tersebut memberi gambaran bahwa konsumsi Fe responden rata-rata di bawah angka kecukupan, yaitu sebesar $35,11 \%$ AKG besi. Hal ini diperkuat dengan rendahnya distribusi tablet tambah darah (TTD), yaitu hanya $17,9 \%$ responden yang masing-masing telah mendapat TTD sebanyak 90 tablet.
Pada masa kehamilan, kebutuhan Fe ibu hamil meningkat dari $26 \mathrm{mg} /$ hari menjadi $39 \mathrm{mg} /$ hari pada trimester ketiga (21). Pada penelitian ini, asupan Fe rata-rata masih di bawah $A K G$, sehingga variabel status konsumsi Fe tidak mampu berperan terhadap terhadap status GAKY.

\section{Hubungan status anemia dengan status GAKY}

Kadar $\mathrm{Hb}$ rata-rata responden sebesar $11,41 \mathrm{~g} / \mathrm{dL}$ $(\mathrm{SD} \pm 1,21)$ atau berkisar antara 8,40-15,80 $\mathrm{g} / \mathrm{dL}$, yang masih tergolong ambang batas anemia bagi ibu hamil $(<11,00 \mathrm{~g} /$ $\mathrm{dL}$ ). Berdasarkan ambang batas tersebut, ibu hamil yang mengalami anemia sebanyak $21(26,9 \%)$ responden dan $57(73,1 \%)$ responden lainnya nonanemia.

Hasil uji statistik Chi Square menunjukkan bahwa tidak ada hubungan antara status anemia dengan status GAKY (gondok) ( $p>0,05)$, namun terdapat hubungan bermakna antara status anemia dengan status GAKY $(\mathrm{TSH})(p<0,05)$. Adapun peluang responden anemia berpeluang menderita GAKY (TSH) sebanyak 7,2 kali $(95 \%$ Cl:1,61-32,25) lebih besar dibanding yang nonanemia.

Penelitian ini memberikan gambaran pada tingkatan klinis,sehingga status anemia (kadar $\mathrm{Hb}$ ) diketahui tidakberpengaruh terhadap status GAKY (gondok), namun pada level biokimia sudah menunjukkan hubungan yang bermakna pada responden dengan kadar $\mathrm{Hb}<11,00 \mathrm{~g} / \mathrm{dL}$ berhubungan erat dengan peningkatan kadar $\mathrm{TSH}>5 \mathrm{mU} / \mathrm{L}$ $(p<0,05)$. Penelitian Sihite et al. (2008) juga melaporkan tidak ada hubungan antara status anemia dengan status GAKY (gondok) (25). Perbedaan kemaknaan hubungan antara status anemia terhadap kejadian GAKY (gondok-

Tabel 3. Hubungan antara tingkat konsumsi yodium, tiosianat dan Fe dengan status GAKY (thyroid stimulating hormone/TSH)

\begin{tabular}{|c|c|c|c|c|c|c|}
\hline \multirow{3}{*}{ Tingkat konsumsi } & \multicolumn{4}{|c|}{ Pemeriksaan TSH } & \multirow{3}{*}{ OR } & \multirow{3}{*}{$\begin{array}{c}p \\
\text { (Cl 95\%) }\end{array}$} \\
\hline & \multicolumn{2}{|c|}{ GAKY } & \multicolumn{2}{|c|}{ Non-GAKY } & & \\
\hline & $\mathrm{n}$ & $\%$ & $\mathrm{n}$ & $\%$ & & \\
\hline \multicolumn{7}{|l|}{ Food recall yodium } \\
\hline Kurang & 6 & 66,7 & 25 & 36,2 & 3,52 & 0,144 \\
\hline Cukup & 3 & 33,3 & 44 & 63,8 & & $(0,81-15,31)$ \\
\hline \multicolumn{7}{|l|}{ FFQ Ikan laut } \\
\hline Rendah & 7 & 77,8 & 21 & 22,5 & 8,00 & $0,009^{*}$ \\
\hline Tinggi & 2 & 22,2 & 48 & 77,5 & & $(1,53-41,78)$ \\
\hline \multicolumn{7}{|l|}{ Food recall tiosianat } \\
\hline Tinggi & 4 & 44,4 & 30 & 43,5 & 1,04 & 1,000 \\
\hline Rendah & 5 & 55,6 & 39 & 56,5 & & $(0,26-4,21)$ \\
\hline \multicolumn{7}{|l|}{ FFQ tiosianat } \\
\hline Tinggi & 5 & 55,6 & 32 & 46,4 & 1,44 & 0,729 \\
\hline Rendah & 4 & 44,4 & 37 & 53,6 & & $(0,36-5,84)$ \\
\hline \multicolumn{7}{|l|}{ Food recall Fe } \\
\hline Rendah & 6 & 66,7 & 26 & 37,7 & 3,31 & 0,149 \\
\hline Tinggi & 3 & 33,3 & 43 & 62,3 & & $(0,76-14,37)$ \\
\hline
\end{tabular}

Keterangan:

FFQ (food frequency questionnaire)

* Bermakna pada $p<0,05$ 
TSH) diduga karena perubahan akibat kekurangan suatu zat gizi terjadi pada level biokimia terlebih dahulu, baru kemudian diikuti perubahan klinis.

Penelitian Zimmermann et al. (2002) menunjukkan bahwa anak yang semula menderita kekurangan yodium atau menderita kekurangan yodium dan $\mathrm{Fe}$, setelah diberi $200 \mathrm{mg}$ kapsul yodium terjadi penurunan volume tiroid ratarata masing-masing sebesar $45,1 \%$ dan $21,8 \%$ (9).

\section{Hubungan status $\mathrm{Pb}$ dengan status GAKY}

Hasil pemeriksaan sampel darah responden menunjukkan kadar $\mathrm{Pb}$ rata-rata responden berkisar antara 0,007-4,18 mg/L. Berdasarkan ambang batas maksimal kadar $\mathrm{Pb}$ dalam darah $(0,4 \mathrm{mg} / \mathrm{L})$ (11), sebanyak 28 $(38,9 \%)$ ibu hamil memiliki kadar $\mathrm{Pb}$ tinggi dan sebanyak $44(61,1 \%)$ responden memiliki kadar $\mathrm{Pb}$ rendah.

Uji statistik Chi Square menunjukkan tidak ada hubungan antara status $\mathrm{Pb}$ dengan status GAKY (gondok) ( $p>0,05$ ). Responden dengan kadar $\mathrm{Pb}$ tinggi berpeluang 1,2 kali $(95 \%$ Cl:0,46-3,10) lebih besar untuk menderita GAKY dibanding responden dengan $\mathrm{Pb}$ normal (Tabel 4). Antara status $\mathrm{Pb}$ dengan status GAKY (TSH) terdapat hubungan bermakna $(p<0,05)$ dan responden yang memiliki kadar $\mathrm{Pb}$ tinggi berpeluang menderita GAKY (TSH) 9,35 kali (95\% $\mathrm{Cl}: 1,03-84,86)$ lebih besar dibanding responden dengan kadar $\mathrm{Pb}$ normal (Tabel 4). Adanya hubungan antara status $\mathrm{Pb}$ dengan status GAKY (TSH) ini menunjukkan pengaruh $\mathrm{Pb}$ sebagai blocking agent yang mengganggu fungsi tiroid dengan menghambat penyerapan yodium ke dalam kelenjar gondok, termasuk kelenjar adrenal dan pituitari (26).

Tidak adanya hubungan antara status $\mathrm{Pb}$ dengan status GAKY (gondok) menunjukkan bahwa proses terjadinya pembesaran gondok tidak hanya dipengaruhi oleh status $\mathrm{Pb}$ yang tinggi. GAKY (gondok) dapat terjadi karena tubuh kekurangan yodium secara terus-menerus dalam jangka waktu lama (13). Dengan demikian, walaupun uji statistik berdasarkan pemeriksaan gondok tidak menunjukkan adanya hubungan, berdasarkan analisa biokimia GAKY (TSH) mengindikasikan adanya peran status $\mathrm{Pb}$ terhadap awal kejadian GAKY (TSH). Hal ini berarti status $\mathrm{Pb}$ tinggi dapat mengganggu penyerapan yodium, namun asupan yodium yang tinggi dapat mempertahankan kecukupan yodium dalam tubuh. Di sisi lain, status $\mathrm{Pb}$ yang rendah dapat menyebabkan kejadian GAKY jika asupan yodium seseorang rendah. Kejadian GAKY juga berhubungan dengan zat gizi lain seperti selenium (Se), seng ( $\mathrm{Zn}$ ), dan logam berat lain seperti $\mathrm{Hg}$ dan $\mathrm{Cd}(7,8)$. Dengan demikian kejadian GAKY pada tiap individu dapat bervariasi penyebabnya.

\section{Hubungan beberapa variabel dengan status GAKY}

Berdasar analisis multivariat berbagai variabel terhadap status GAKY (gondok), hanya variabel status konsumsi sumber yodium (FFQ) dari ikan laut yang bermakna $(p<0,05)$. Responden dengan status konsumsi ikan laut yang rendah $($ skor $<33,53)$ berpeluang menderita GAKY (gondok) 3,69 kali (95\% Cl:1,239-9,112) lebih besar dibanding responden yang mengkonsumsi ikan laut lebih tinggi setelah mengontrol variabel status konsumsi yodium (food recall) (Tabel 5). Perbedaan tingkat kemaknaan antara metode pengumpulan status yodium FFQ dan food recall terhadap status GAKY (gondok) disebabkan food recall (2×24 jam) cenderung lebih menggambarkan konsumsi yodium pada saat tersebut, sedangkan metode FFQ menggambarkan kebiasaan makan individu dalam rentang waktu lama (6 bulan). GAKY dapat terjadi akibat kekurangan yodium secara terus-menerus dalam waktu lama (13).

Model akhir regresi logistik terhadap status GAKY (TSH) menunjukkan ada dua variabel yang secara

Tabel 4. Hubungan antara status anemia dan status $\mathrm{Pb}$ terhadap status GAKY (gondok dan TSH)

\begin{tabular}{|c|c|c|c|c|c|c|}
\hline \multirow{2}{*}{ Status } & \multicolumn{2}{|c|}{ GAKY } & \multicolumn{2}{|c|}{ Non-GAKY } & \multirow{2}{*}{ OR } & \multirow{2}{*}{$\begin{array}{c}p \\
(95 \% \mathrm{Cl})\end{array}$} \\
\hline & $\mathbf{n}$ & $\%$ & $\mathbf{n}$ & $\%$ & & \\
\hline \multicolumn{7}{|l|}{ Pemeriksaan gondok } \\
\hline \multicolumn{7}{|l|}{ Status anemia } \\
\hline Anemia & 14 & 36,8 & 7 & 17,5 & 2,75 & 0,054 \\
\hline Nonanemia & 24 & 63,2 & 33 & 82,5 & & $(0,96-7,85)$ \\
\hline \multicolumn{7}{|l|}{ Status $\mathrm{Pb}$} \\
\hline Tinggi & 14 & 41,2 & 14 & 36,8 & 1,20 & 0,706 \\
\hline Normal & 20 & 58,8 & 24 & 63,2 & & $(0,46-3,10)$ \\
\hline \multicolumn{7}{|l|}{ Pemeriksaan TSH } \\
\hline \multicolumn{7}{|l|}{ Status anemia } \\
\hline Anemia & 6 & 66,7 & 15 & 21,7 & 7,20 & 0,010 \\
\hline Nonanemia & 3 & 33,3 & 54 & 88,5 & & $(1,61-32,25)$ \\
\hline \multicolumn{7}{|l|}{ Status $\mathrm{Pb}$} \\
\hline Tinggi & 5 & 83,3 & 23 & 34,8 & 9,35 & $0,030^{*}$ \\
\hline Normal & 1 & 16,7 & 43 & 65,2 & & $(1,03-84,86)$ \\
\hline
\end{tabular}

Keterangan:

* Bermakna pada $p<0,05$ 
Tabel 5. Hasil akhir regresi logistik terhadap status GAKY

\begin{tabular}{lccccc}
\hline \multicolumn{1}{c}{ Variabel } & B & Sig. & OR & \multicolumn{2}{c}{$\mathbf{9 5 \% ~ C l ~}$} \\
\cline { 5 - 6 } & & & & Lower & Upper \\
\hline Pemeriksaan gondok & 0,938 & 0,060 & 2,56 & 0,960 & 6,801 \\
Status yod & 1,306 & 0,011 & 3,69 & 1,346 & 10,124 \\
Status FFQ ikan laut & $-1,357$ & 0,012 & & & \\
Constant & & & & & \\
Pemeriksaan TSH & 3,011 & 0,017 & 20,32 & 1,697 & 243,288 \\
Status anemia & 1,976 & 0,123 & 7,22 & 0,585 & 89,090 \\
Status Pb & 2,545 & 0,045 & 12,75 & 1,055 & 154,084 \\
Status FFQ ikan laut & $-0,773$ & 0,373 & & & \\
Constant & &
\end{tabular}

bersamaan dapat mempengaruhi kejadian GAKY (TSH), yaitu status konsumsi yodium melalui $F F Q$ pada sumber yodium ikan laut dan status anemia $(p<0,05)$. Responden dengan konsumsi ikan laut yang rendah (skor $<33,53$ ) berpeluang menderita GAKY (TSH) sebanyak 12,75 kali (95\% Cl:1,055-154,084) lebih besar dibanding responden yang mengkonsumsi ikan laut lebih tinggi setelah mengontrol variabel status $\mathrm{Pb}$. Responden anemia $(<11,00$ $\mathrm{g} / \mathrm{dL}$ ) berpeluang menderita GAKY (TSH) 20,32 kali (95\% $\mathrm{Cl}: 1,697-243,288)$ lebih besar dibandingkan dengan responden tidak anemia setelah mengontrol variabel status $\mathrm{Pb}$ (Tabel 5).

Di antara kedua variabel yang berhubungan dengan status GAKY (TSH) tersebut, status anemia $(<11,00 \mathrm{~g} /$ $\mathrm{dL}$ ) merupakan variabel yang paling dominan dengan OR sebesar 20,32 kali. Hal ini disebabkan variabel status konsumsi yodium yang diuji hanya berasal dari tingkat konsumsi ikan laut, sehingga belum menggambarkan konsumsi yodium sebenarnya. Status anemia berdasarkan kadar $\mathrm{Hb}$ dalam darah $(<11,0 \mathrm{~g} / \mathrm{dL})$ merupakan level status gizi pada tingkat biokimia yang sama seperti kadar TSH dalam serum. Hal ini sesuai dengan penelitian yang menunjukkan bahwa status kekurangan $\mathrm{Fe}$ akan memperparah keadaan GAKY(9) serta penambahan Fe dan yodium melalui fortifikasi pangan dapat meningkatkan kadar Fe dalam tubuh (10).

Kandungan $\mathrm{Pb}$ yang berlebihan dalam tubuh akan menghambat penyerapan yodium, sehingga mengganggu fungsi kelenjar adrenal dan pituitari (26). Selain mengganggu penyerapan yodium, $\mathrm{Pb}$ dapat menyebabkan anemia karena menghambat reaksi sentesis heme (11). Teori tersebut menggambarkan keterkaitan antara yodium- $\mathrm{Fe}-\mathrm{Pb}$-yodium yang merupakan rangkaian mineral saling bersinergi yang pada akhirnya bisa memperparah kejadian penyakit. Berdasar hasil analisis regresi logistik dalam penelitian ini, status $\mathrm{Pb}$ merupakan faktor pengganggu, baik terhadap status anemia (selisih OR $63,12 \%$ ) maupun status konsumsi yodium dari ikan laut (selisih OR 34,83\%).

Faktor penyebab status $\mathrm{Pb}$ sebagai faktor pengganggu dapat dihubungkan dengan sumber cemaran $\mathrm{Pb}$ tersebut dalam bahan makanan. Hal ini sesuai dengan penelitian Rahman (2006) yang menyebutkan hasil udang dan rajungan dipantai Kalimantan Selatan mengandung kadar $\mathrm{Pb}$ yang melebihi batas normal FAO yaitu $2 \mathrm{ppm}$, sedangkan kandungan $\mathrm{Pb}$ pada subjek penelitian berkisar antara 66,995-96,25 ppm (12).

Tingginya kandungan $\mathrm{Pb}$ pada sebagian jenis makanan laut menyebabkan status $\mathrm{Pb}$ dalam tubuh menjadi pengganggu dalam model ini. Idealnya, makin banyak konsumsi makanan laut, asupan yodium akan meningkat, namun penting pula diperhatikan mengingat adanya peningkatan kadar $\mathrm{Pb}$ sebagai penghambat penyerapan yodium. Hasil ikan laut juga merupakan salah satu sumber Fe yang penting bagi tubuh karena memiliki bioavaibilitas yang tinggi. Peningkatan konsumsi ikan laut akan meningkatkan asupan $\mathrm{Fe}$ guna peningkatan $\mathrm{Fe}(\mathrm{Hg})$, sehingga pada akhirnya akan membantu peningkatan penyerapan yodium. Adanya logam $\mathrm{Pb}$ pada bahan makanan tersebut akan menjadi faktor pengganggu, baik penyerapan yodium maupun pembentukan heme.

\section{KESIMPULAN DAN SARAN}

Terdapat hubungan antara tingkat konsumsi yodium (ikan laut) berdasarkan FFQ terhadap status GAKY (gondok dan TSH), antara status konsumsi yodium berdasarkan FFQ ikan laut terhadap status GAKY (gondok) setelah mengontrol variabel status konsumsi yodium (food recall), antara status konsumsi yodium (FFQ) pada sumber yodium ikan laut bersama variabel status anemia terhadap status GAKY (TSH) setelah mengontrol variabel status $\mathrm{Pb}$, antara status anemia dengan status GAKY (TSH), dan antara status $\mathrm{Pb}$ dengan status GAKY (TSH).

Berdasarkan kesimpulan di atas, dapat diberikan saran antara lain: sebaiknya distribusi kapsul yodium bagi sasaran beriringan dengan pembagian tablet tambah darah sesuai dengan status GAKY individu guna menurunkan prevalensi GAKY dan anemia di Kecamatan Tabunganen Kabupaten Barito Kuala, penurunan kadar $\mathrm{Pb}$ dalam darah oleh tim medis, dan perlu dilakukan penelitian lebih lanjut tentang kandungan $\mathrm{Pb}$ pada berbagai bahan makanan laut, serta penanggulangan dan pencegahan pencemaran $\mathrm{Pb}$ oleh Bapedalda Provinsi Kalimantan Selatan. 


\section{RUJUKAN}

1. Tim Penanggulangan GAKY Pusat, DepkesRI. Panduan penegakan norma sosial, peningkatan konsumsi garam beryodium kesehatan masyarakat. Jakarta: Depkes RI; 2004.

2. Greenspan FS, Baxter JD.Endokrinologi dasar \& klinik(Basic \& Clinical Endocrinology). Edisi 4. Jakarta: Buku Kedokteran EGC; 2000.

3. Soekirman. IImu gizi dan aplikasinya untuk keluarga dan masyarakat. Jakarta: Dirjen Dikti, Depdiknas; 2000.

4. Hartono B. Perkembangan fetus dalam kondisi defisiensi yodium dan cukup yodium.Jurnal GAKY Indonesia 2002; 1(1): 19-26.

5. Tim Penanggulangan GAKY Pusat. Rencana aksi kesinambungan program penanggulangan gangguan akibat kekurangan yodium. Jakarta: Depkes RI; 2005.

6. Thaha AR, Dachlan DM, Jafar N. Analisis faktor risiko coastal goiter. Jurnal GAKY Indonesia 2002; 1(1): 9-17.

7. Satoto.selenium dan kurang yodium. Jurnal GAKY Indonesia 2002;1(1): 33-40.

8. Andriani M, Wirjatmadi B,Gunanti IR. Identifikasi gondok di daerah pantai: suatu akibat kekurangan yodium?.Jurnal GAKY Indonesia 2002; 3 (1): 17-28.

9. Zimmermann M, Adou P, Hurrell R. Iron supplementation in goitrous, iron-deficient children improves their response to oral iodized oil. Eur J Endocrinol 2000;142 (3): 217-23.

10. Wegmulle R, Camara F, Zimmermann MB, Adou P, Urrell RF. Salt dual-fortified with iodine and micronized ground ferric pyrophosphate affects iron status but not hemoglobin in children in cote d'ivoire.J Nutr 2006; 136: $1814-60$.

11. Linder $M C$, editor. Biokimia nutrisi dan metabolisme dengan pemakain secara klinis.Jakarta: Penerbit UI; 2006.

12. Rahman $\mathrm{A}$. Kandungan logam berat timbal $(\mathrm{Pb})$ dan kadmium (Cd) pada beberapa jenis krustasea di Pantai Batakan dan Takisung Kabupaten Tanah Laut Kalimantan Selatan. Jurnal Bioscientiae 2006: 3 (2): 93-101.

13. WHO. Assesment of iodine deficiency disorders and monitoring their elimination. A guide for programme managers. 3 rd ed; Geneva;2007.
14. Djokomoeljanto R. Evaluasi masalah gangguan akibat kurang yodium (GAKY) di Indonesia. Jurnal GAKY Indonesia 2002;3 (1): 1-5.

15. Vaidya B, Anthony S, Bilous M, Shields B, Drury J, Hutchison S, Bilous R. Detection of thyroid dysfunction in early pregnancy: universal screening or targeted high-risk case finding? J Clin Endocrinol \& Metab 2007;92(1): 203-7.

16. Guyton AC, Hall JE. Fisiologi kedokteran (textbook of medical physiology). Alih Bahasa Irawati Setiawan, Penerjemah Irawati Setiawan dkk. Jakarta; Penerbit Buku Kedokteran: 1993.

17. Gomo AR, Allain TJ, Matenga JA, Ndemere B, Wilson A., Urdal P.Urinary iodine concentrations and thyroid function in adult zimbabweans during a period of transition in iodine status.Am J Clin Nutr1999; 70: 888-891.

18. Aoki Y, Belin RM, Clickner R, Jeffries R, Phillips L, Mahaffey KR. Serum TSH and total t4 in united states population and their association with participant characteristics: national health and nutrition examination survey (NHANES 1999-2002). J Thyroid 2007;17 (12): 1211-23.

19. Kiratli PO, Gedik GK. Problems and pitfalls in thyroid uptake measurements with iodine-131. Hell J Nucl Med2008; 11 (3): 187-8.

20. WHO, FAO. Vitamin and mineral requirement in human nutrition. $2^{\text {nd }} e d$. Geneva; 2004.

21. Kartono D, Soekarti M. Angka kecukupan mineral: besi, yodium, seng, mangan, selenium. Prosiding Widyakarya Nasional Pangan dan Gizi VIII; 2004 May 17-19; Jakarta; 2004. p.393-416.

22. Soeharyo H, Margawati A, Setiawan H, Djokomoelyanto. Aspek sosial kultur pada program penanggulangan GAKY. Jurnal GAKY Indonesia2002; 1(1): 41-6.

23. Murdiana A, Saidin S.Penentuan makanan yang mengandung goitrogenik tiosianat sebagai salah satu faktor timbulnya GAKY. Bogor: Puslitbang Gizi; 2001.

24. WHO. Hydrogen cyanide and cyanides: human health aspect. Geneva; 2004.

25. Sihite GTD, Sudargo T, Adiyanti MG. Hubungan antara status gangguan akibat kekurangan yodium (GAKY), status anemia dengan prestasi belajar anak sekolah dasar di Kabupaten Dairi Provinsi Sumatera Utara. Jurnal Gizi Klinik Indonesia 2008; 4 (3): 125-32.

26. Zens C. Occupational medicine, principles and practical application. $2^{\text {nd }}$ ed. Chicago; 1988. 